Louisiana State University

LSU Digital Commons

Faculty Publications

Department of Geology and Geophysics

$1-1-1999$

\title{
Ecological legacies: Impacts on ecosystems of the McMurdo Dry Valleys
}

Daryl L. Moorhead

The University of Toledo

Peter T. Doran

University of Illinois at Chicago

Andrew G. Fountain

Portland State University

W. Berry Lyons

The University of Alabama

Diane M. McKnight

University of Colorado Boulder

See next page for additional authors

Follow this and additional works at: https://digitalcommons.Isu.edu/geo_pubs

\section{Recommended Citation}

Moorhead, D., Doran, P., Fountain, A., Lyons, W., McKnight, D., Priscu, J., Virginia, R., \& Wall, D. (1999).

Ecological legacies: Impacts on ecosystems of the McMurdo Dry Valleys. BioScience, 49 (12), 1009-1019. https://doi.org/10.1525/bisi.1999.49.12.1009

This Article is brought to you for free and open access by the Department of Geology and Geophysics at LSU Digital Commons. It has been accepted for inclusion in Faculty Publications by an authorized administrator of LSU Digital Commons. For more information, please contact ir@lsu.edu. 


\section{Authors}

Daryl L. Moorhead, Peter T. Doran, Andrew G. Fountain, W. Berry Lyons, Diane M. McKnight, John C. Priscu, Ross A. Virginia, and Diana H. Wall 


\section{Ecological Legacies: Impacts on Ecosystems of the McMurdo Dry Valleys}

DARYL L. MOORHEAD, PETER T. DORAN, ANDREW G. FOUNTAIN, W. BERRY LYONS, DIANE M. MCKNIGHT, JOHN C. PRISCU, ROSS A. VIRGINIA, AND DIANA H. WALL

\begin{abstract}
cosystems are seldom isolated, either in space or Gin time, but the functional linkages among the lake, stream, and soil ecosystems of the Antarctic dry valleys are unusual in that they operate over millennial-scale time periods. Recently, the concept of ecological legacies has emerged as a framework for elucidating the influence of past events on the structure and behavior of extant ecosystems. An ecological legacy is defined as the carryover, or memory, of the system with regard to past events (Little et al. 1997, Vogt et al. 1997). Thus, ancient pools of inorganic nutrients and organic matter represent resource legacies of past climate regimes that influence the modern polar deserts of the McMurdo Dry Valleys (South Victoria Land, Antarctica).

This definition of legacy is enormously flexible, both in how it can be interpreted and in what it implies about the time scales at which legacies operate (Vogt et al. 1997). Recent studies of ecological legacies have focused primarily on community- or ecosystem-level phenomena, on changes due to previous events occurring within the same or similar ecosystems, on time scales ranging from decades to centuries, and on anthropogenic impacts. For example, Kirkman et al. (1996) and Little et al. (1997) found that legacies of land use have had enduring impacts on wetland plant communities of South Carolina and upland ecosystems of Ireland, respectively. Similarly, Wallin et al. (1994) noted that forest landscape patterns in the Pacific Northwest of the United States are persistent legacies of harvesting practices and are difficult to change in the short term.

Factors other than land-use history also generate legacies affecting subsequent ecosystems. For example, Tausch
\end{abstract}

\author{
THE TYPES, AMOUNTS, AND LOCATIONS \\ OF CARBON AND NUTRIENT LEGACIES
}

DEMONSTRATE STRONG FUNCTIONAL

LINKS BETWEEN ANCIENT AND MODERN

ECOSYSTEMS OF THE MCMURDO DRY

\section{VALLEYS}

et al. (1993) proposed that the composition of modern plant communities in North America is largely a legacy of climate change during the Quaternary because changes in vegetation often lag behind changes in climate. Legacies of past climate regimes also exert a strong influence on the structure and function of current ecosystems in the McMurdo Dry Valleys, even though the prevailing climatic conditions remained those of a cold desert throughout the Quaternary (Denton et al. 1993, Marchant and Denton 1996). Life forms within the dry valleys were presumably restricted to microbiota during this time; therefore, ecosystems in the Antarctic dry valleys responded to climate changes in a different way than the plant communities discussed by Tausch et al. (1993). Successive changes in the structure of plant communities are often controlled by "higher-order" interactions between species, such as competition (Connell and Slatyer 1977). In contrast, the extreme climate, low biodiversity, short food chains, and paucity of higher trophic groups in the dry valleys (Freck-

Daryl L. Moorhead (e-mail: dmoorhe@uoft02.utoledo.edu) is an associate professor in the Department of Biological Sciences, University of Toledo, Toledo, OH 43606-3390. Peter T. Doran (e-mail: pdoran@uic.edu) is an assistant professor in the Department of Earth and Environmental Sciences, University of Illinois, Chicago, IL 60607-7059. Andrew G. Fountain (e-mail: fountain@pdx.edu) is an adjunct professor in the Department of Geology, Portland State University, Portland, OR 97207-0751. W. Berry Lyons (e-mail: blyons@wgs.geo.ua.edu) is a professor of geochemistry and Loper Chair of Environmental Geology in the Department of Geology, University of Alabama, Tuscaloosa, AL 35487-0338. Diane M. McKnight (e-mail: mcknight@snobear.colorado.edu) is an associate professor in the Department of Civil, Environmental, and Architectural Engineering, University of Colorado, Boulder, CO 80309-0450. John C. Priscu (e-mail: ubijp@gemini.oscs.montana.edu) is a professor of ecology in the Department of Biological Sciences, Montana State University, Bozeman, MT 59717. Ross A. Virginia (e-mail: ross.a.virginia@dartmouth.edu) is a professor and chair of Environmental Studies, Dartmouth College, Hanover, NH 03755. Diana H. Wall (e-mail: diana@ nrel.colostate.edu) is director of the Natural Resource Ecology Laboratory and a professor in the Department of Rangeland Ecosystem Science, Colorado State University, Fort Collins, CO 80523. ㅇ 1999 American Institute of Biological Sciences. 
a

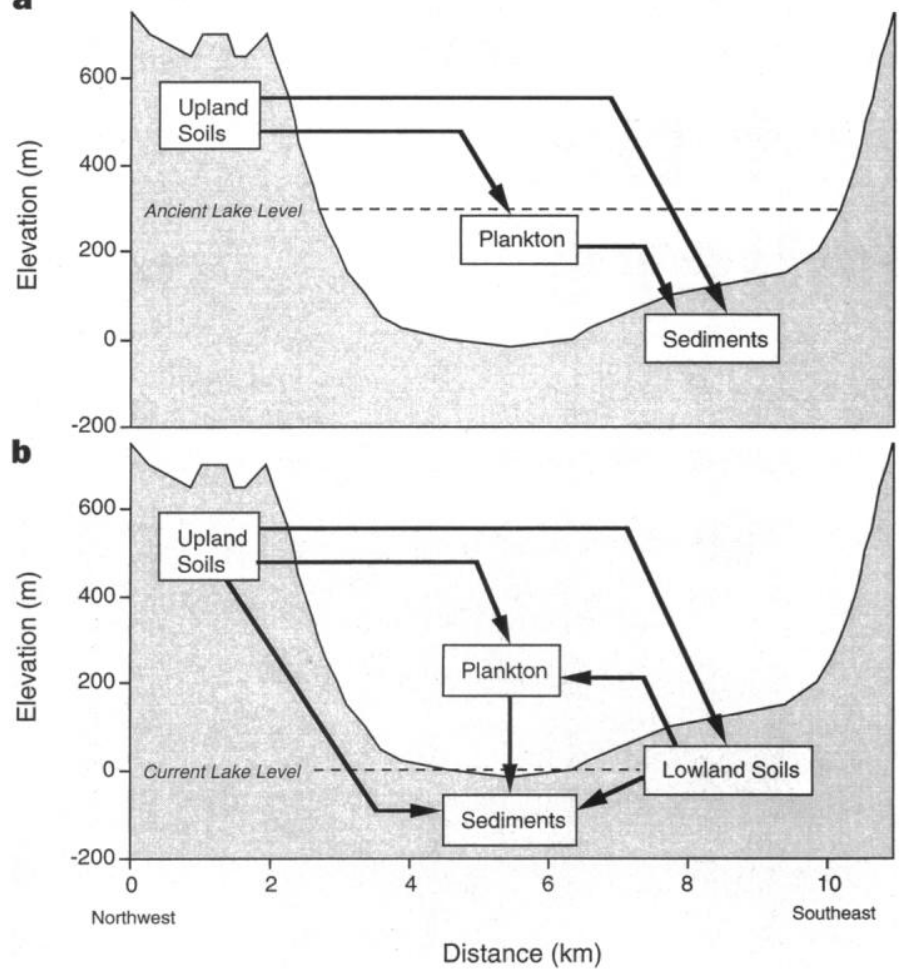

Figure 1. Cross-sections of the Lake Fryxell basin, Taylor Valley, Antarctica. (a) Approximate depth of Lake Washburn (approximately 20,000 years ago). (b) Approximate depth of modern Lake Fryxell. Flow diagrams represent primary fluxes of organic carbon (see also Virginia and Wall 1999, Burkins et al. in press). between ancient and modern ecosystems of the McMurdo Dry Valleys and provide information about the long-term responses of dry valley ecosystems to changing abiotic conditions (i.e., climate and hydrology).

\section{Disequilibria and resource legacies in the dry valleys}

The net accumulation or reduction of a resource pool that constitutes a legacy necessarily requires a disequilibrial system because a system that operates at equilibrium neither increases nor decreases the net sizes of resource pools over time. Recent studies confirm that many components of the dry valley landscape are not at equilibrium (Lyons et al. 1997, 1998c, Priscu et al. 1999, Virginia and Wall 1999). The most obvious signs of disequilibrium in the McMurdo Dry Valleys are the pools of organic matter in soils of the valley bottoms as well as carbon and nutrients in deep waters of the valley lakes. These resource legacies appear to be the result of cycles of inundation and desiccation of the valley floor (Figure 1).

Although the dry valleys have been hyper-arid, cold desert environments since the middle Miocene, fluctuations in climate have driven glacial advances and retreats during the Quaternary, with attendant variations in hydrology and lake levels (Denton et al. 1989, 1993). The balance between solid ice and liquid water is delicately poised during the austral summer, and so small changes in precipitation, temperature, and radiant energy regimes are amplified through large, nonlinear changes in hydrologic budgets (Dana et al. 1998) that ramify throughout the system (Figure 2). Glaciers provide more meltwater during times of warmer temperatures and greater precipitation, which increases stream flow and lake volume. Conversely, colder and drier conditions result in less glacier melt, lower stream flow, and declining lake volume (Fountain et al. 1999).

Because the presence of liquid water remains the primary limiting condition for life in Antarctica (Kennedy 1993), subtle differences in climate have profound effects on the productivity, biogeochemistry, and biodiversity of the dry valleys (Fountain et al. 1999). For example, changes in hydrology, in which ancient lakes inundated large areas of the dry valleys that are presently exposed (Figure 1a), were responsible for accumulations of lacustrine organic matter in modern soils at low elevations in the valleys. Primary production of benthic and planktonic algae supplied organic matter that was deposited in sediments of these deep, ancient lakes. This organic matter is a potential source of energy to modern soil food webs and of allochthonous input to modern lakes as exposed soils are eroded by wind and water (Figure $1 \mathrm{~b}$ ). Thus, the cycles of inundation and desiccation to which lowland areas were subjected resulted in alternating periods of organic matter deposition to and erosion from lowland soils (Fig- 
Figure 2. Conceptual model of temporal cycles between periods of warm/moist and cold/dry conditions, with attendant changes in hydrology and dynamics of organic matter and inorganic nutrients (Taylor Valley, Antarctica). Outer, middle, and inner loops represent changing climatic, hydrologic, and soil water conditions, respectively. Solid lines represent temporal trajectories, and dashed lines represent forcing functions. The model shows that climate drives hydrology, which drives organic matter deposition and erosion, as well as chemical accumulation and concentration.

ure 2). Pools of inorganic nutrients and salts also accumulated in lowland soils and lakes, probably as a result of hydrologic regimes (Priscu et al. 1999, Virginia and Wall 1999).

At higher elevations, changes in climate had less impact on the soil environment because hydrologic fluctuations were limited to streambeds - that is, the soils were not inundated (Figure 1). Thus, two patterns of long-term ecosystem dynamics emerge for soils, depending on landscape position: the valley bottoms were dominated by cycles of glacial intrusion (Taylor Glacier and Ross Ice Sheet), lacustrine inundation, and lake desiccation, whereas the upland areas experienced cycles of alpine glacier expansion and fluctuating precipitation (Denton et al. $1989,1993)$. This scenario is consistent with the recent observation that organic matter in lowland soils appears to be derived from marine and lacustrine sources, whereas organic matter in upland soils has an isotopic signature $\left(\delta^{13} \mathrm{C}\right.$ and $\left.\delta^{15} \mathrm{~N}\right)$ that is similar to modern endolithic communities living within sandstone rocks at high elevations (Burkins et al. in press).

The disequilibrial nature of dry valley systems is also demonstrated by the chemical composition of existing lakes (Priscu et al. 1999). The basins occupied by modern lakes in Taylor Valley were part of the larger Lake Washburn, which inundated the valley to approximately $300 \mathrm{~m}$ above current lake levels approximately 24,000-6000 years ago (Denton et al. 1989, 1993). However, the deep waters of present-day Taylor Valley lakes, particularly Lake Bonney, contain high concentrations of nutrients and solutes (e.g., salts of calcium, chloride, or sulfate) and appear to be remnants of smaller, hypersaline lakes that existed before or after Lake Washburn (Matsubaya et al. 1979, Spigel and Priscu 1996, Priscu et al. 1999). The permanent ice layers on dry valley lakes maintain stable stratification of the water column, thereby minimizing mixing of water and solutes between depths. Therefore, inputs of glacier and stream water, which have low concentrations of solutes, flow under permanent ice covers but float on top of denser water containing higher concentrations of solutes. As a result, deeper waters contain pools of evaporites and

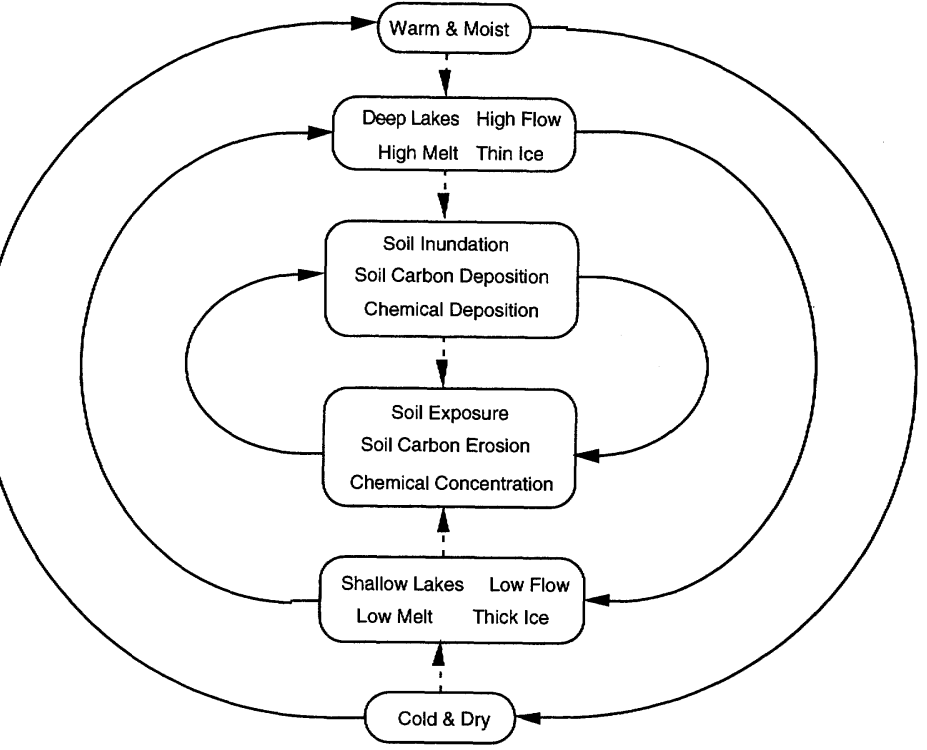

nutrients that accumulated over time and that remain largely separated from surface waters by a persistent vertical gradient. Cycles of inundation and desiccation would not dilute solute concentrations in deep water so long as the stable vertical gradient within the water column remained intact (Lyons et al. 1998a, 1998b, 1998c).

\section{Ecosystems and legacies in the dry valleys}

According to the conceptual model of dry valley ecosystems developed in this issue, community structure and dynamics are primarily controlled by resource availabilities and environmental conditions. Fluctuations in climate generate hydrological cycles that have large impacts on biogeochemical processes (Figure 2), generating resource legacies that will affect ecosystems in subsequent centuries or millennia. Past, present, and future ecosystems are functionally linked by these legacies; therefore, understanding the long-term dynamics of the dry valleys will require an understanding of both the production and the use of these legacies.

Two of the most obvious resource legacies in dry valley ecosystems are the pools of organic matter and inorganic nutrients in modern soils and lakes. However, the extent to which these legacies exist, affect, and are affected by particular communities varies between communities and over time. Moreover, a community may simultaneously operate as both source and sink for resource legacies, with net balances determined by the state of the hydrological cycle (i.e., inundated versus desiccated; Figure 1) as well as community characteristics.

Lakes. In modern lakes of the dry valleys, nutrient pools residing in deeper waters are resource legacies that affect the production of existing phytoplankton communities (Priscu et al. 1999). Primary production of plankton in the surface, illuminated (euphotic) zones of dry valley lakes is 
Table 1. Pools of nitrogen and carbon representing resource legacies in Lake Hoare, Southern Victoria Land, Antarctica. ${ }^{a}$

\begin{tabular}{|c|c|c|c|c|c|}
\hline Depthb (m) & $\begin{array}{l}\text { Dissolved inorganic } \\
\text { nitrogen (kg) }\end{array}$ & $\begin{array}{l}\text { Particulate organic } \\
\text { nitrogen (kg) }\end{array}$ & $\begin{array}{l}\text { Dissolved inorganic } \\
\text { carbon (kg) }\end{array}$ & $\begin{array}{l}\text { Dissolved organic } \\
\text { carbon (kg) }\end{array}$ & $\begin{array}{l}\text { Particulate organlc } \\
\text { carbon }(\mathrm{kg})\end{array}$ \\
\hline 5 & 1.7 & 6.9 & $4,396.6$ & 466.2 & 134.1 \\
\hline 6 & 3.2 & 21.1 & $26,252.8$ & 1724.0 & 320.3 \\
\hline 8 & 0.0 & 42.9 & $58,908.7$ & 3811.0 & 594.3 \\
\hline 10 & 0.0 & 33.2 & $54,617.7$ & 3569.4 & 468.6 \\
\hline 12 & 0.0 & 35.0 & $63,203.0$ & 3707.4 & 473.2 \\
\hline 14 & 13.4 & 27.6 & $64,675.5$ & 3507.5 & 383.8 \\
\hline 16 & 39.3 & 18.0 & $62,993.6$ & 3197.1 & 266.6 \\
\hline 18 & 61.1 & 11.5 & $59,559.7$ & 2737.0 & 189.7 \\
\hline 20 & 56.1 & 7.5 & $50,412.4$ & 2216.2 & 152.4 \\
\hline 22 & 50.7 & 5.5 & $40,919.0$ & 1857.5 & 122.5 \\
\hline 25 & 77.5 & 5.1 & $41,084.6$ & 1848.4 & 115.4 \\
\hline 29 & 101.7 & 2.9 & $23,027.0$ & 971.9 & 59.6 \\
\hline below 29 & 39.3 & 0.8 & $6,427.2$ & 261.8 & 15.2 \\
\hline
\end{tabular}

limited by availabilities of nitrogen and phosphorus (Priscu 1995), which are at low concentration despite the large pools of nutrients in deeper water (Tables 1 and 2). The upward diffusion of nutrients from deeper water supports primary production of plankton in all lakes in Taylor Valley, especially at lower depths within the euphotic zone (Priscu 1995, Priscu et al. 1999). Therefore, the modern production of organic matter links the existing nutrient legacy to a future legacy of organic matter that is currently being deposited in lake sediments. For this reason, the dynamics of both ecosystems and resource legacies in the dry valleys are tightly integrated.

The nutrients in the deep waters of dry valley lakes are of uncertain origin, but the sizes of nutrient pools in lakes of Taylor Valley imply that they have accumulated over long periods (Priscu et al. 1999). Stable stratification contributes to the isolation and retention of nutrients in deep water, with particulate deposition providing input to deep water and molecular diffusion serving as the primary mechanism for upward movement (Spigel and Priscu 1998, Priscu et al. 1999). Nutrients in deeper waters may be regenerated from mineralization of settling organic matter derived from both allochthonous and autochthonous sources or from deposition during the evolution of the lakes (Priscu et al. 1999). Alternatively, nutrients within the water column could have been concentrated during periods of lake desiccation and retained within smaller, residual ponds. As discussed previously, subsequent inflows of glacial meltwater would have contained fewer solutes and floated on the surface of these denser pools of water, with permanent ice covers maintaining stable stratification. However they originated, nutrient pools in deep waters of dry valley lakes are probably long-term legacies of past processes. As Priscu (1997) noted, molecular diffusion would imply a 50,000year mixing time for Lake Bonney, suggesting that nutrients have accumulated in deeper water for many millennia (cf., Chinn 1993, Doran et al. 1999).

Comparisons between the resource legacies and ecosys- tem dynamics of two lakes in Taylor Valley, Lake Bonney and Lake Hoare, are instructive because Lake Hoare is much younger than Lake Bonney. Both lakes have a nutrient legacy in deeper water, nutrient-limited phytoplankton productivity, and a deep chlorophyll maximum that is supported by upward diffusion of nutrients (Priscu 1995). However, Lake Hoare apparently dried or drained completely approximately 1200 years ago, whereas Lake Bonney may be more than 10,000 years old (Chinn 1993, Doran et al. 1994a, 1994b, Lyons et al. 1997, 1998c). Because the approximate age of Lake Hoare is known, current water chemistry data can be used to calculate rates of nitrogen accumulation over this period (Table 1). To amass the existing pool of dissolved inorganic nitrogen (which, in the form of ammonium plus nitrate plus nitrite, amounts to $27 \mathrm{mg} \cdot \mathrm{m}^{-3}$ ) would require an average nitrogen accumulation rate of $370 \mathrm{~g} \cdot \mathrm{yr}^{-1}$, or $191 \mu \mathrm{g} \cdot \mathrm{m}^{-2} \cdot \mathrm{yr}^{-1}$, given the present surface area of Lake Hoare (approximately $1.94 \times 10^{6} \mathrm{~m}^{2}$ ). The pool of inorganic nitrogen in the water column of Lake Bonney (approximately $2 \mathrm{~g} \cdot \mathrm{m}^{-3}$ ) is much larger than that of Lake Hoare, suggesting a longer period or faster rate of accumulation, although insufficient data exist to directly evaluate these differences. More detailed nutrient budgets have not been determined for dry valley lakes, but additional understanding of the origins and dynamics of nutrient legacies may be gained by examining carbon budgets because carbon and nutrient flows are linked in all ecosystems.

An obvious feature of the carbon budget for Lake Bonney is the large imbalance in carbon flux between the surface water layer and deeper water (Priscu et al. 1999). The annual input of organic carbon from the surface euphotic zone to the deeper waters of the lake $\left(8556 \mathrm{mg} \cdot \mathrm{m}^{-2}\right)$ is an order of magnitude greater than the diffusion of dissolved organic and inorganic carbon in the opposite direction $\left(719 \mathrm{mg} \cdot \mathrm{m}^{-2}\right)$. Decay of particulate organic matter is too slow to fully account for these diffusion losses from deep water (Priscu 1992, Takacs and Priscu 1998, Voytek et al. 
Table 2. Pools of nitrogen and carbon representing resource legacies in Lake Bonney (east lobe), Southern Victoria Land, Antarctica. ${ }^{a}$

\begin{tabular}{|c|c|c|c|c|c|}
\hline Depth' (m) & $\begin{array}{l}\text { Dlssolved Inorganlc } \\
\text { nltrogen (kg) }\end{array}$ & $\begin{array}{l}\text { Partlculate organic } \\
\text { nitrogen (kg) }\end{array}$ & $\begin{array}{l}\text { Dissolved Inorganlc } \\
\text { carbon (kg) }\end{array}$ & $\begin{array}{l}\text { Dissolved organlc } \\
\text { carbon (kg) }\end{array}$ & $\begin{array}{l}\text { Particulate organlc } \\
\text { carbon (kg) }\end{array}$ \\
\hline 5 & 73.8 & 13.6 & $10,538.0$ & $1,549.7$ & 219.3 \\
\hline 6 & 287.5 & 29.5 & $23,288.8$ & $3,653.1$ & 492.4 \\
\hline 8 & 736.7 & 63.3 & $68,800.9$ & $6,705.2$ & 1174.6 \\
\hline 10 & 857.8 & 47.9 & $96,564.7$ & $7,531.5$ & 1044.7 \\
\hline 12 & $1,148.8$ & 43.6 & $165,396.7$ & $7,439.1$ & 876.3 \\
\hline 13 & 908.9 & 22.9 & $148,165.3$ & $4,233.3$ & 509.4 \\
\hline 15 & $2,368.5$ & 27.6 & $391,076.7$ & $10,079.3$ & 793.6 \\
\hline 18 & $6,550.5$ & 18.2 & $638,602.0$ & $27,792.2$ & 592.0 \\
\hline 20 & $8,027.1$ & 50.5 & $526,030.7$ & $43,898.4$ & 833.1 \\
\hline 22 & $10,709.0$ & 99.0 & $582,726.6$ & $66,577.5$ & 1299.1 \\
\hline 25 & $18,447.7$ & 103.9 & $622,783.1$ & $107,852.4$ & 1279.5 \\
\hline 30 & $33,121.2$ & 109.0 & $444,753.7$ & $163,554.6$ & 1312.3 \\
\hline 35 & $25,631.0$ & 101.9 & $176,888.7$ & $113,913.7$ & 1087.3 \\
\hline 37 & $4,577.2$ & 17.8 & $29,779.8$ & $24,292.8$ & 193.8 \\
\hline below 37 & $2,485.5$ & 7.1 & $12,325.8$ & $13,140.7$ & 87.1 \\
\hline
\end{tabular}

1998), and ${ }^{14} \mathrm{C}$ ages indicate that dissolved inorganic carbon in deep water may have originated approximately 8000 years ago (Doran et al. 1999). These observations suggest that the deeper waters of Lake Bonney contain a legacy of inorganic carbon and that they presently serve as a sink for organic carbon; these observations also suggest that interactions between pools of organic and inorganic carbon in deep waters are limited at the present time. The sources of carbon entering and already existing in Lake Bonney are not known for certain, but aeolian inputs of materials to the surface of the ice cover (Adams et al. 1998, Fritsen et al. 1998) may account for much of the organic matter entering deeper waters. Rates of organic carbon sedimentation for Lake Bonney (Priscu et al. 1999) imply a nitrogen input rate of approximately $744 \mathrm{mg} \cdot \mathrm{m}^{-2} \cdot \mathrm{yr}^{-1}$ to sediments, given a C:N ratio of approximately 11.5:1 (Wharton et al. 1993). The contributions of sediments to dissolved carbon and nitrogen pools in deeper water appear to be low but are impossible to estimate at present because standing stocks and turnover rates of benthic organic matter in Lake Bonney are unknown.

A detailed carbon budget has not been estimated for Lake Hoare, but it shares with Lake Bonney a number of general features of carbon and nutrient legacies. Pools of organic matter, carbon, and nutrients are present in the sediments and deeper waters of Lake Hoare (Doran et al. 1994b, Priscu 1995). Windblown materials collect on the permanent ice cover of Lake Hoare and subsequently enter the underlying water column through cracks and channels in the ice (Simmons et al. 1986, Squyres et al. 1991), suggesting an aeolian input similar to that of Lake Bonney (Adams et al. 1998, Fritsen et al. 1998). Parker et al. (1982) calculated that wind erosion causes a loss of organic carbon from the margins of Lake Hoare, but this loss was small compared to sediment inputs and has not been verified by direct measurements. Thus, like Lake Bonney,
Lake Hoare appears to serve as a net sink for organic carbon. In addition, Doran et al. (1999) dated dissolved inorganic carbon in Lake Hoare to approximately 1120 years ago, indicating a legacy of inorganic carbon, albeit much younger than that in Lake Bonney. Detailed analyses of benthic sediment cores from Lake Hoare provide insights to organic matter deposition that are not possible for Lake Bonney. Simple calculations based on sediment data can be used for additional comparisons of the carbon and nitrogen budgets of these lakes.

Sediment cores in Lake Hoare show discontinuities in diatom assemblages and ${ }^{14} \mathrm{C}$ dates at approximately $15 \mathrm{~cm}$ depth; these discontinuities correspond roughly to the estimated age of 1200 years for this lake (Doran et al. 1994b, Spaulding et al. 1997). The total organic matter content of the top $15 \mathrm{~cm}$ of sediments is approximately $0.15 \%$ by weight (Doran et al. 1994b), which represents approximately $203 \mathrm{~g} \cdot \mathrm{m}^{-2}$ of carbon, assuming that the sediment bulk density is $1.8 \mathrm{~g} \cdot \mathrm{cm}^{-3}$ and half the mass of organic matter is carbon. If the organic matter has a C:N ratio of 11.5:1 (Wharton et al. 1993), then the top $15 \mathrm{~cm}$ of sediments in Lake Hoare have a nitrogen concentration of approximately $18 \mathrm{~g} \cdot \mathrm{m}^{-2}$. These data suggest accumulation rates of approximately $169 \mathrm{mg} \cdot \mathrm{m}^{-2} \cdot \mathrm{yr}^{-1}$ for carbon and $15 \mathrm{mg} \cdot \mathrm{m}^{-2} \cdot \mathrm{yr}^{-1}$ for nitrogen. The finding that the calculated rate of nitrogen input to sediments of Lake Hoare is almost 100 -fold greater than the estimated rate of accumulation for dissolved inorganic nitrogen in the water column is interesting because it suggests extremely slow turnover rates for particulate organic matter. In addition, the finding that rates of carbon and nitrogen inputs to sediments of Lake Hoare are more than an order of magnitude smaller than the respective rates calculated for modern Lake Bonney is interesting because it suggests different rates of aeolian inputs of materials to lake surfaces. However, existing data are insufficient to explain these dif- 
ferences in sediment dynamics between Lake Hoare and Lake Bonney. Moreover, it is not possible to calculate a rate at which dissolved inorganic nitrogen accumulated in Lake Bonney because the age of the lake is uncertain.

Characteristics of the organic matter in sediment cores of Lake Hoare offer additional insights to the dynamics of carbon and nutrient legacies in dry valley lakes. The organic matter content of these sediments is not uniform but decreases from approximately $1 \%$ at the surface (excluding the surface microbial mat) to $0.1 \%$ at $15 \mathrm{~cm}$ depth (Doran et al. 1994b). This proportional reduction in organic matter with depth suggests progressive mineralization. Indeed, the $\delta^{13} \mathrm{C}$ value of organic matter was found to increase with depth in sediments (Doran et al. 1994b), which often happens because decaying organic matter disproportionately retains heavier isotopes. Wharton et al. (1994) reported that many sediment profiles in Lake Hoare were oxygenated to depths of $15 \mathrm{~cm}$, indicating that decay should not be limited by a lack of oxygen. For these reasons, it appears that organic matter has decomposed in sediments of Lake Hoare over the past 1200 years. By contrast, deep waters of Lake Bonney have low oxygen concentrations, low levels of biological activity, and low rates of decomposition. The difference between Lakes Hoare and Bonney suggests that younger, shallower lakes may have greater biological activity in benthic regions. Indeed, the higher oxygen concentrations and lower salinity levels of deep waters in Lake Hoare are less likely to inhibit biological activity than the lower oxygen and higher salinity of deep waters in Lake Bonney. Moreover, high concentrations of metals in deep waters of Lake Bonney may inhibit biological activity (Ward and Priscu 1997).

The sediments of Lake Hoare and settling organic matter in Lake Bonney probably originate from sediments deposited by wind on the permanent ice covers of these lakes (Simmons et al. 1986, Squyres et al. 1991, Adams et al. 1998, Fritsen et al. 1998). The sources of these materials are probably the exposed soils near the dry valley lakes, which contain pools of organic matter and nutrients (Virginia and Wall 1999, Fritsen et al. in press). In fact, Doran et al. (1999) dated suspended particulate organic carbon in Lake Hoare to between 13,530 and 10,280 years ago, which falls within the period during which glacial Lake Washburn inundated Taylor Valley (Denton et al. 1989). These materials may represent organic matter deposited in sediments of ancient lakes that is now being eroded from exposed soils and deposited in modern lakes, where it is accumulating in benthic sediments.

However, the activities of modern biological communities may alter the carbon and nutrient characteristics of this aeolian material as it passes through the ice covers, settles through the water columns, and accumulates in lake sediments (Wharton et al. 1993, Doran et al. 1994b, 1998, Priscu et al. 1999). For example, the organic carbon content of soils near Lake Hoare is approximately $0.034 \%$ (Powers et al. 1998), which is lower than that of benthic sediments in
Lake Hoare (0.15-1\%; Doran et al. 1994b), implying in situ addition of organic matter. Organic matter within the water column and sediments of Lake Hoare appears to mineralize more rapidly than that of Lake Bonney, suggesting that modern ecosystems vary in their effects on pools of organic matter and nutrients in dry valley lakes.

Soils. Organic matter is widely distributed throughout soils of the dry valleys. As previously discussed, much of the organic matter in soils may be a legacy of past primary production and currently serves as a source of allochthonous material received by lakes (Figure 1). It is also possible that modern soil communities derive their energy from these pools of ancient organic matter (Virginia and Wall 1999). Alternatively, modern soil communities might contribute to existing pools of soil organic matter through in situ primary production.

Although the organic matter content of dry valley soils is very low (less than $0.1 \%$ dry soil weight; Campbell et al. 1998), it represents a large fraction of the total pool of organic matter in the dry valley landscape. For example, Freckman and Virginia (1997) reported an average of $0.08 \%$ organic carbon content in soils of the McMurdo Dry Valleys, which represents approximately $216 \mathrm{~g} \cdot \mathrm{m}^{-2}$ in the upper $15 \mathrm{~cm}$ of the soil profile and compares to the estimates of approximately $203 \mathrm{~g} \cdot \mathrm{m}^{-2}$ in the upper $15 \mathrm{~cm}$ of the sediment profile in Lake Hoare that were given above. Over $90 \%$ of the nonglaciated surface area of Taylor Valley consists of soil and rock, so that much of the seasonally active (unfrozen) reservoir of organic carbon appears to reside in soils (Virginia and Wall 1999). Because organic matter is indicative of biological activity, the distribution and origin of organic matter in dry valley soils may reveal the basis of patterns of biological activities in this seemingly inhospitable environment.

The amount and origin of organic matter in dry valley soils vary with location. In general, the organic matter content of soils decreases with elevation and with distance from the mouth of Taylor Valley (Powers et al. 1998, Virginia and Wall 1999, Fritsen et al. in press). For example, Fritsen et al. (in press) found surface soils (0-2 cm depth) with an organic carbon content approaching $0.2 \%$ near the mouth of Taylor Valley, whereas values in the upper valley near Lake Bonney rarely exceeded $0.02 \%$. Microclimate differences within the dry valley may contribute to these patterns, with the increased precipitation, lower temperatures, and reduced wind at the valley's mouth supporting more biological activity (Fountain et al. 1999). However, geological factors are also likely to play an important role in determining the distributions and origins of soil organic matter. For example, much of the soil organic matter at low elevations in Taylor Valley has an isotopic signature indicating a lacustrine origin and a distribution that corresponds roughly to the spatial extent of the glacial lakes that inundated the valley (Burkins et al. in press). Few isotopic analyses have been made for organic 
matter in soils located at elevations above the direct influence of ancient glacial lakes. However, many of these upland surfaces are extremely old (Marchant and Denton 1996) and may serve as long-term repositories of organic matter produced by endolithic communities in sandstone formations at higher elevations (Nienow and Friedmann 1993).

The potential sources of organic matter found in dry valley soils have been discussed elsewhere (Denton et al. 1989, 1993, Nienow and Friedmann 1993, Burkins et al. 1998, in press, Virginia and Wall 1999). Four sources may play current roles in modifying the legacy of soil organic matter: in situ primary production, exfoliation and aeolian transport from endolithic communities, aeolian transport of modern algal mats from streams and lakes, and erosion of exposed sediments from ancient lake beds.

In situ primary production. There is little indication of present-day in situ primary production in dry valley soils. Although algal cells and chlorophyll are widely distributed, there is no evidence of in situ photosynthesis, and Wynn-Williams et al. (1997) found no evidence of recent colonization of soils by microalgae in Taylor Valley. Indeed, the simple presence of viable algal cells or chlorophyll is not sufficient to demonstrate biological activity, even within aquatic environments in the dry valleys (Howard-Williams et al. 1989, Hawes et al. 1992, McKnight et al. 1999). In addition to dispersed cells, algal crusts have also been reported in soils of the Antarctic dry valleys (Cameron et al. 1970). In warm deserts, cryptogamic crusts can make significant contributions to energy and nitrogen dynamics in soils (Moore 1998), and photosynthesis can be activated in these crusts by very small amounts of dew, fog, and atmospheric humidity (Lange et al. 1992, 1994, 1998). Perhaps in situ production does occur in dry valley soils at present, but sporadically and at very low levels. It is also likely that soil conditions have varied with climate in Taylor Valley, with the warmer, moister conditions of the past having supported in situ photosynthesis and microalgal colonization of soils.

Exfoliation and aeolian transport from endolithic communities. In contrast to soil communities, endolithic communities of the dry valleys are active at the present time and may be a modern source of soil organic matter. Endolithic communities consist of a consortium of algae, fungi, and bacteria colonizing sandstone formations (Friedmann and Kibler 1980, Vestal 1988, Friedmann et al. 1993). Organic acids produced by the fungi dissolve cavities between sand grains, providing a protected environment in which the community persists. Polysaccharide mucilages produced by microalgae moderate moisture conditions, with precipitation providing both moisture and nitrogen (Friedmann and Kibler 1980). Photosynthetic carbon fixation by microalgae provides an energy source for heterotrophic microorganisms. Although rates of primary production by these communities are low (carbon fixation rates are approximately $3 \mathrm{mg} \cdot \mathrm{m}^{-2} \cdot \mathrm{yr}^{-1}$; Fried- mann et al. 1993), weathering and exfoliation of rock surfaces provide a source of organic matter to the surrounding soils.

Standing carbon stocks are low (approximately $2.54 \mathrm{~g}$ carbon per square meter of inhabited rock surface; Vestal 1988), and distributions of modern endolithic communities are limited, but the long-term environmental stability of the high-elevation environments in which endoliths occur (cf., Marchant and Denton 1996) suggest that a substantial amount of organic matter may have accumulated in some sites. For example, a net carbon production rate of $3 \mathrm{mg} \cdot \mathrm{m}^{-2} \cdot \mathrm{yr}^{-1}$ over 1 million years would yield organic carbon in the amount of $3 \mathrm{~kg} \cdot \mathrm{m}^{-2}$. This latter estimate is much higher than any reported value of organic matter in soils of the dry valleys, but Nienow and Friedmann (1993) proposed that endolithic communities are a significant source of organic matter that is distributed by wind to lower elevations. Indeed, isotopic signatures of soil organic matter at higher elevations in Taylor Valley have been found to be similar to those of endolithic materials (Burkins et al. in press).

Aeolian transport of modern algal mats. There is clear evidence of aeolian transport of microbial mats from streams and lakes of the dry valleys to nearby soil surfaces (Priscu et al. 1999, Fritsen et al. in press). The streams are dry during much of the year, and exposed mats desiccate and are eroded by winds during these periods (McKnight et al. 1999). Benthic microbial mats in shallow lake zones can detach from sediments and be lifted to the underside of the permanent ice layer by entrained gas bubbles. Parker et al. (1982) proposed that water freezing on the underside of the ice cover and ablating from the upper surface creates a conveyor system that carries these "lift-off" mats through the ice to where they are exposed and can be transported by wind throughout the valleys. These losses of organic matter from streams and lakes appear to be small relative to amounts received from and residing in soils. However, the younger material may be of higher quality and more readily used by soil communities. Indeed, Virginia and Wall (1999) note that soil community structure varies with distance from dry valley streams. Unfortunately, the sources, qualities, and quantities of organic matter in aeolian materials have not yet been determined, nor have the net exchanges among soils, streams, and lakes of the dry valleys been quantified, so it is difficult to know the relative importances of modern and ancient sources of organic matter to current ecosystems.

Erosion of exposed sediments from ancient lake beds. Probably the largest and most obvious sources of organic matter in soils of the dry valleys are the ancient lakes that once inundated the valley bottoms. Geomorphological features (Denton et al. 1993, Marchant and Denton 1996), paleolimnological evidence (Doran et al. 1994a), and recent isotopic analyses of soil organic matter (Virginia and Wall 1999, Burkins et al. in press) support the general hypothesis that an ancient lake inundated much of Taylor 
Valley between 24,000 and 6000 years ago (Figure 1). Thus, present-day erosion of organic matter from soils in the valley bottoms both reduces the net size of this resource legacy in exposed soils and increases the net size of this legacy in sediments of modern lakes. The impacts of these inputs on lake ecosystems are, as discussed above, uncertain (see also Priscu et al. 1999), but the relationships between organic matter pools in soils and modern soil communities are even more uncertain.

Biota are widely distributed in dry valley soils (Powers et al. 1995, 1998, Freckman and Virginia 1997, Virginia and Wall 1999), and distributions of soil biota are related to multiple factors, including salinity, water, and carbon content of soils (Powers et al. 1995, 1998, Freckman and Virginia 1997, 1998, Virginia and Wall 1999). Field and laboratory measurements of $\mathrm{CO}_{2}$ efflux are indicative of low but detectable rates of respiration in dry valley soils (Burkins 1998). There is no indication that in situ primary production supports soil respiration, so the energy driving soil food webs may be supplied by the reservoir of soil organic matter. As more observations of the energetics of soil food webs are made and more detailed characterizations of soil organic matter become available, a clearer picture of the relationships between modern soil communities and organic matter reservoirs should emerge.

\section{Legacies and linkages in dry valley landscapes}

Ecosystem dynamics and spatial patterns of present-day dry valley landscapes are stongly influenced by the climate and hydrological regimes that occurred over the past several thousand years. The cycle of valley inundation, lacustrine deposition of organic matter in sediments, lake desiccation, erosion of organic matter from exposed soils, and redeposition of organic matter in sediments of smaller, modern lakes (Figures 1 and 2) defines a complex relationship between pools of organic matter and nutrients in soils and lakes that requires millennia to complete. Thus, the terrestrial and aquatic ecosystems of the Antarctic dry valleys are inextricably linked through the dynamics of such resource legacies (Moorhead and Priscu 1998).

The premise of the synthesis in this article is that resource legacies, especially those found at low elevations in Taylor Valley, are generated by hydrological cycles driven by climate regime (Figures 1 and 2) and have effects on dry valley ecosystems that persist over subsequent millennia. Lowland soils receive lacustrine deposits of organic matter when inundated and serve as sources of sediments to smaller, interglacial lakes when exposed (Figure 1). In modern lakes, nutrient pools residing in deeper waters are resource legacies that support the production of existing phytoplankton communities (Priscu et al. 1999). Therefore, the modern production of organic matter in lakes links the existing nutrient legacy to a future legacy of organic matter currently being deposited in lake sediments. Consequently, the dynamics of ecosystems and resource legacies in the dry valleys are tightly coupled. Studies evaluating the quantities, sources, ages, and exchanges among pools of organic matter throughout the dry valleys, as well as the patterns of energy and nutrient flux in extant ecosystems, are providing the data needed to understand long-term geological and ecological histories of this unique environment (Fountain et al. 1999, McKnight et al. 1999, Priscu et al. 1999, Virginia and Wall 1999).

Our knowledge of dry valley ecosystems has many gaps. For example, it is not certain if ancient glacial lakes served as net carbon and nutrient sinks for the Taylor Valley landscape, if they had permanent ice covers, or if they were more autotrophic than modern lakes. The smaller, modern lakes currently serve as sinks for organic matter received by sediment input, and in situ primary production may not meet respiratory demands (Priscu et al. 1999). By analogy, ancient lakes may have also served as sinks for allochthonous organic matter derived from terrestrial sources rather than generating the organic matter deposited in lake sediments by in situ primary production. Organic matter apparently cascades through these ecosystems over long periods of time, stimulating biological activities under favorable circumstances that, in turn, alter both quantities and qualities of this resource pool. Evidence for this idea comes from the finding that $\delta^{13} \mathrm{C}$ values of benthic microbial mats in Lake Hoare are at the lighter end of the range for lacustrine materials (Virginia and Wall 1999), overlapping endolithic signatures and suggesting more in situ primary production (Wharton et al. 1993) than indicated by $\delta^{13} \mathrm{C}$ values of ancient lacustrine materials in nearby soils.

The distributions and characteristics of soil organic matter demonstrate differences in ecosystem dynamics in space as well as over time. Organic matter and nutrients in lowland soils appear to represent legacies of past lacustrine regimes, whereas similar legacies in upland soils may have originated from endolithic communities. Modern soils provide suitable habitats for a diversity of organisms whose distribution and activity are influenced, in part, by legacies of soil organic matter (Virginia and Wall 1999). Primary production has not been detected in dry valley soils, so the question remains as to what energy source drives modern soil systems in what location. Another important spatial dimension in dry valley ecosystems is the stable stratification of water columns in lakes having permanent ice covers. Materials entering deeper water by sedimentation or evaporitic reduction in lake volume can exit only by molecular diffusion (Priscu et al. 1999). This difference in input and output rates establishes a partial chronological record of lake dynamics that is captured within the spatial dimension of the water column. Continuing studies of the patterns and processes of communities living at particular locations within the water columns of dry valley lakes are providing knowledge of the conditions under which these gradients developed and the ways in which they affect extant communities (Priscu et al. 1999). 
The McMurdo Dry Valleys provide a singular opportunity to learn about ancient patterns of ecosystem dynamics through the biological legacies they generated. The geologic stability, geographic isolation, and prevailing polar desert climate of the region provide a milieu in which biological activity has probably remained consistently low and undergone few qualitative changes over 1-2 million years. The food webs contain few species, mostly microbiota, whose activity patterns are tightly coupled to microenvironmental variations that may change significantly over small distances (Priscu et al. 1999, Virginia and Wall 1999) and short time spans (Fountain et al. 1999, McKnight et al. 1999). However, large-scale spatial patterns of biological relevance, such as distributions of biota, organic matter, nutrients, and water (Fountain et al. 1999, McKnight et al. 1999, Priscu et al. 1999, Virginia and Wall 1999), have a temporal dimension that is defined in large part by variations in climate (Figures 1 and 2). Resource legacies not only establish functional linkages between ecosystems over time but also indicate how patterns of biological activities varied through time. The legacies that we have discussed (i.e., organic matter and nutrients) are tightly coupled to biological activities and yet persist in reactive forms for much longer periods of time in the dry valleys than in any other environment. The patterns of use, production, and distribution of resource legacies in the Antarctic dry valleys should therefore help reveal the role of legacies in other ecosystems, where their expression is obscured by greater complexity and higher rates of biological, chemical, and geological processes.

\section{Epilogue: human impacts}

It is ironic that one of the most isolated environments on Earth is experiencing the impacts of human activities, which will generate additional legacies affecting the future existence of these fragile ecosystems. Indeed, one of the first indications of global ozone depletion was observed over Antarctica, and the recorded increases in lake levels in Taylor Valley since the turn of the century (Chinn 1993) may be a reflection of global warming. The impacts of increasing levels of ultraviolet radiation on dry valley ecosystems are uncertain, but major changes in the physical, biological, and chemical characteristics of the lakes would clearly result if changes in climate caused the loss of the permanent ice covers. Legacies now preserved by stable stratification of the water column would be lost if winds caused circulation between depths.

In addition to impacts of global changes, human activities are having direct, local effects on the Antarctic dry valleys. Early explorers and later scientists generated perturbations that may persist for millennia (Harris 1998). For example, many camps and supply depots have remained essentially unchanged over the decades since their establishment. Arid conditions, cold temperatures, and lack of higher organisms insures their preservation, illustrating the potential for long-term impacts of materi- als left in the valleys. Scientists have also had a variety of inadvertent impacts on the dry valleys, especially before effective waste treatment and petrochemical containment procedures were enacted. Even footprints have the potential to disrupt fragile soil structure, a fact that underscores the potential consequences of a growing ecotourism industry to the dry valley ecosystems. As mentioned by McKnight et al. (1999), increasing foot traffic in such sensitive areas as streambeds could disrupt communities that would take decades or centuries to reestablish. The scientific community is taking steps to minimize negative impacts on Antarctic ecosystems, but the means of controlling tourist access to Antarctica remain politically ambiguous (Harris 1998).

\section{Acknowledgments}

We wish to thank Melody B. Burkins, Andy Parsons, and Amy Treonis. Financial support for this work was provided by National Science Foundation grant nos. OPP9211773 (to the McMurdo Long-Term Ecological Research program); DPP88-20591, OPP91-17907, OPP94-19423, OPP98-15512 (to J. C. P.); DEB 9115734, OPP 9120123, and OPP 9421025 (to D. H. W. and R. A. V.). NASA Exobiology Program grant no. NAGW 1947 to Robert A. Wharton Jr. supported work by P. T. D.

\section{References cited}

Adams EE, Priscu JC, Fritsen CH, Smith SR, Brackman SL. 1998. Permanent ice covers of the McMurdo Dry Valley Lakes: Bubble formation and metamorphism. Pages 281-296 in Priscu JC, ed. Ecosystem Dynamics in a Polar Desert: The McMurdo Dry Valleys, Antarctica. Antarctic Research Series, Vol. 72. Washington (DC): American Geophysical Union.

Burkins MB. 1998. The origin, distribution, and cycling of soil organic matter in Taylor Valley, Antarctica. PhD dissertation. Dartmouth College, Hanover, NH.

Burkins MB, Chamberlain CP, Virginia RA, Freckman DW. 1998. Natural abundance of carbon and nitrogen isotopes in potential sources of organic matter to soils of Taylor Valley, Antarctica. Antarctic Journal of the United States 31: 209-210.

Burkins MB, Virginia RA, Chamberlain CP, Wall DH. In press. The origin of soil organic matter in Taylor Valley, Antarctica: A legacy of climate change. Ecology.

Cameron RE, King J, David CN. 1970. Soil microbial ecology of Wheeler Valley, Antarctica. Soil Science 100: 110-120.

Campbell IB, Claridge GGC, Campbell DI, Balks MR. 1998. The soil environment of the McMurdo Dry Valleys, Antarctica. Pages 297-322 in Priscu JC, ed. Ecosystem Dynamics in a Polar Desert: The McMurdo Dry Valleys, Antarctica. Antarctic Research Series, Vol. 72. Washington (DC): American Geophysical Union.

Carpenter SR, ed. 1988. Complex Interactions in Lake Communities. New York: Springer-Verlag.

Chinn TJ. 1993. Physical hydrology of the Dry Valley Lakes. Pages 1-52 in Green WJ, Friedmann EI, eds. Physical and Biological Processes in Antarctic Lakes. Antarctic Research Series, Vol. 59. Washington (DC): American Geophysical Union.

Connell JH, Slatyer RO. 1977. Mechanisms of succession in natural communities and their role in community stability and organization. American Midland Naturalist 11: 1119-1144.

Dana GL, Wharton RA Jr, Dubayah R. 1998. Solar radiation in the McMurdo Dry Valleys, Antarctica. Pages 39-65 in Priscu JC, ed. Ecosystem Dynamics in a Polar Desert: The McMurdo Dry Valleys, Antarctica. 
Antarctic Research Series, Vol. 72. Washington (DC): American Geophysical Union.

Denton GH, Bockheim JG, Wilson SC, Stuiver M. 1989. Late Wisconsin and Early Holocene glacial history, Inner Ross embayment, Antarctica. Quaternary Research 31: 151-182.

Denton GH, Sugden DE, Marchant DR, Hall DL, Wilch TI. 1993. East Antarctic ice sheet sensitivity to Pliocene climatic change from a dry valleys perspective. Geografiska Annaler 75: 155-204.

Doran PT, Wharton RA Jr, Lyons WB. 1994a. Paleolimnology of the McMurdo Dry Valleys, Antarctica. Journal of Paleolimnology 10: 85-114.

Doran PT, Wharton RA Jr, Spaulding SA, Foster JS. 1994b. McMurdo LTER: Paleolimnology of Taylor Valley, Antarctica. Antarctic Journal of the United States 29: 234-237.

Doran PT, Wharton RA Jr, Des Marais D, McKay CP. 1998. Antarctic paleolake sediments and the search for extinct life on Mars. Journal of Geophysical Research-Planets 103: 28481-28493.

Doran PT, Berger G, Wharton RA Jr, Lyons WB, Davisson L, Southon J, Dibb J. 1999. Dating Quaternary lacustrine sediments in the McMurdo Dry Valleys Antarctica: Tackling the carbon reservoir effect. Palaeography, Palaeoclimatology, Palaeoecology 147: 223-239.

Fountain AG, et al. 1999. Physical controls on the Taylor Valley ecosystem, Antarctica. BioScience 49: 961-971.

Freckman DW, Virginia RA. 1997. Low-diversity Antarctic soil nematode communities: Distribution and response to disturbance. Ecology 78: $363-369$.

. 1998. Soil biodiversity and community structure in the McMurdo Dry Valleys, Antarctica. Pages 323-336 in Priscu JC, ed. Ecosystem Dynamics in a Polar Desert: The McMurdo Dry Valleys, Antarctica. Antarctic Research Series, Vol. 72. Washington (DC): American Geophysical Union.

Friedmann EI, Kibler AP. 1980. Nitrogen economy of endolithic microbial communities in hot and cold deserts. Microbial Ecology 6: 95-108.

Friedmann EI, Kappen L, Meyer MA, Nienow JA. 1993. Long-term productivity in the cryptoendolithic microbial community of the Ross Desert, Antarctica. Microbial Ecology 25: 51-69.

Fritsen CH, Adams EE, McKay CM, Priscu JC. 1998. Permanent ice covers the McMurdo Dry Valley lakes, Antarctica: Liquid water content. Pages 269-280 in Priscu JC, ed. Ecosystem Dynamics in a Polar Desert: The McMurdo Dry Valleys, Antarctica. Antarctic Research Series, Vol. 72. Washington (DC): American Geophysical Union.

Fritsen $\mathrm{CH}$, Grue A, Priscu JC. In press. Distribution of organic carbon and nitrogen in surface soils in the McMurdo Dry Valleys, Antarctica. Polar Biology.

Harris CM. 1998. Science and environmental management in the McMurdo Dry Valleys, Southern Victoria Land, Antarctica. Pages 337-350 in Priscu JC, ed. Ecosystem Dynamics in a Polar Desert: The McMurdo Dry Valleys, Antarctica. Antarctic Research Series, Vol. 72. Washington (DC): American Geophysical Union.

Hawes I, Howard-Williams C, Vincent WF. 1992. Desiccation and recovery of Antarctic cyanobacterial mats. Polar Biology 12: 587-594.

Howard-Williams C, Pridmore R, Downes MT, Vincent WF. 1989. Microbial biomass, photosynthesis and chlorophyll $a$ related pigments in the ponds of the McMurdo Ice Shelf, Antarctica. Antarctic Science 1: 125-131.

Kennedy AD. 1993. Water as a limiting factor in the Antarctic terrestrial environment: A biogeographical synthesis. Arctic and Alpine Research 25: 308-315.

Kirkman LK, Lide RF, Wein G, Sharitz RR. 1996. Vegetation changes and land-use legacies of depression wetlands of the western coastal plain of South Carolina: 1951-1992. Wetlands 16: 564-576.

Lange OL, Kidron GJ, Büdel B, Meyer A, Kilian E, Abeliovich A. 1992. Taxonomic composition and photosynthetic characteristics of the 'biological soil crusts' covering sand dunes in the western Negev Desert. Functional Ecology 6: 519-527.

Lange OL, Meyer A, Büdel B. 1994. Net photosynthesis activation of a desiccated cyanobacterium without liquid water in high arid humidity alone. Experiments with Microcoleus sociatus isolated from a desert soil crust. Functional Ecology 8: 52-57.

Lange OL, Belnap J, Reichenberger H. 1998. Photosynthesis of the cyanobacterial soil-crust lichen Collema tenax from arid lands in southern Utah, USA: Role of water content on light and temperature responses of $\mathrm{CO}_{2}$ exchange. Functional Ecology 12: 195-202.

Little D, Farrell E, Collins J. 1997. Land-use legacies and soil development in semi-natural ecosystems in the marginal uplands of Ireland. Catena 30: 83-98.

Lyons WB, Mayewski PA, Bartek LR, Doran PT. 1997. Climate history of the McMurdo Dry Valleys since the last glacial maximum. Pages 15-22 in Lyons WB, Howard-Williams C, Hawes I, eds. Ecosystem Processes in Antarctic Ice-Free Landscapes. Rotterdam (The Netherlands): A. A. Balkema.

Lyons WB, Welch KA, Neumann K, Toxey JK, McArthur R, Williams C, McKnight DM, Moorhead DL 1998a. Geochemical linkages among glaciers, streams, and lakes within the Taylor Valley, Antarctica. Pages 77-92 in Priscu JC, ed. Ecosystem Dynamics in a Polar Desert: The McMurdo Dry Valleys, Antarctica. Antarctic Research Series, Vol. 72. Washington (DC): American Geophysical Union.

Lyons WB, Welch KA, Sharma P. 1998b. Chlorine-36 in the waters of the McMurdo Dry Valley lakes, southern Victoria Land, Antarctica: Revisited. Geochimica et Cosmochimica Acta 62: 185-191.

Lyons WB, Tyler SW, Wharton RA Jr, McKnight DM, Vaughn BH. 1998c. A Late Holocene desiccation of Lake Hoare and Lake Fryxell, McMurdo Dry Valleys, Antarctica. Antarctic Science 10: 247-256.

Marchant DR, Denton GH. 1996. Miocene and Pliocene paleoclimate of the Dry Valleys region, Southern Victoria land: A geomorphological approach. Marine Micropaleontoloty 27: 253-271.

Matsubaya O, Sakai H, Torii T, Burton H, Kerry K. 1979. Antarctic saline lakes-stable isotopic ratios, chemical compositions and evolution. Geochimica et Cosmochimica Acta 43: 7-25.

McKnight DM, Niyogi DK, Alger AS, Bomblies A, Conovitz PA, Tate CM. 1999. Dry valley streams in Antarctica: Ecosystems waiting for water. BioScience 49: 985-995.

Moore PD. 1998. Life in the upper crust. Nature 393: 419-420.

Moorhead DL, Priscu JC. 1998. The McMurdo Dry Valley ecosystem: Organization, controls, and linkages. Pages 351-363 in Priscu JC, ed. Ecosystem Dynamics in a Polar Desert: The McMurdo Dry Valleys, Antarctica. Antarctic Research Series, Vol. 72. Washington (DC): American Geophysical Union.

Nienow JA, Friedmann EI. 1993. Terrestrial lithophytic (rock) communities. Pages 343-412 in Friedmann EI, ed. Antarctic Microbiology. New York: John Wiley \& Sons.

Parker BC, Simmons GM, Wharton RA Jr, Seaburg KA, Love FG. 1982. Removal of organic and inorganic matter from Antarctic lakes by aerial escape of bluegreen algal mats. Journal of Phycology 18: 72-78.

Powers LE, Freckman DW, Virginia RA. 1995. Spatial distribution of nematodes in polar desert soils of Antarctica, Polar Biology 15: 325-334.

Powers LE, Ho M, Freckman DW, Virginia RA. 1998. Distribution, community structure and microhabitats of soil biota along an elevational gradient in Taylor Valley, Antarctica. Arctic and Alpine Research 30: 133-141.

Priscu JC. 1992. Particulate organic matter decomposition in the water column of Lake Bonney, Taylor Valley, Antarctica. Antarctic Journal of the United States 27: 260-262.

1995. Phytoplankton nutrient deficiency in lakes of the McMurdo Dry Valleys, Antarctica. Freshwater Biology 34: 215-227.

. 1997. The biogeochemistry of nitrous oxide dynamics in permanently ice-covered lakes of the McMurdo Dry Valleys, Antarctica. Global Change Biology 3: 301-315.

Priscu JC, Wolf DF, Takacs CD, Fritsen CH, Laybourn-Parry J, Roberts EC, Sattler B, Lyons WB. 1999. Carbon transformations in a perennially ice-covered Antarctic lake. BioScience 49: 997-1008.

Simmons GM Jr, Wharton RA Jr, McKay CP, Nedell S, Clow GA. 1986. Sand/ice interactions and sediment deposition in perennially ice-covered lakes. Antarctic Journal of the United States 21: 217-220.

Spaulding SA, McKnight DM, Stoermer EF, Doran PT. 1997. Diatoms in sediments of perennially ice-covered Lake Hoare, and implications for 
interpreting lake history in the McMurdo Dry Valleys of Antarctica. Journal of Paleolimnology 17: 403-420.

Spigel RH, Priscu JC. 1996. Evolution of temperature and salt structure of Lake Bonney, a chemically stratified Antarctic lake. Hydrobiologia 321: 177-190.

1998. Physical limnology of the McMurdo Dry Valleys lakes. Pages 153-187 in Priscu JC, ed. Ecosystem Dynamics in a Polar Desert: The McMurdo Dry Valleys. Antarctic Research Series, Vol. 72. Washington (DC): American Geophysical Union.

Squyres SW, Anderson DW, Nedell SS, Wharton RA Jr. 1991. Lake Hoare, Antarctica: Sedimentation through a thick perennial ice cover. Sedimentology 38: 363-379.

Takacs CD, Priscu JC. 1998. Bacterioplankton dynamics in the McMurdo Dry Valley Lakes: Production and biomass loss over four seasons. Microbial Ecology 36: 239-250.

Tausch RJ, Wigand PE, Burkhardt JW. 1993. Viewpoint: Plant community thresholds, multiple steady states, and multiple successional pathways: Legacy of the Quaternary. Journal of Range Management 46: 439-447.

Vestal JR. 1988. Carbon metabolism of the cryptoendolithic microbiota from the Antarctic desert. Applied and Environmental Microbiology 54: 960-965.

Virginia RA, Wall DH. 1999. How soils structure communities in the Antarctic dry valleys. BioScience 49: 973-983.

Vogt KA, et al. 1997. Ecosystems: Balancing Science with Management. New York: Springer-Verlag.

Voytek MA, Ward BB, Priscu JC. 1998. The abundance of ammonium-oxidizing bacteria in Lake Bonney, Antarctica, determined by immunofluorescence, PCR, and in situ hybridization. Pages 217-228 in Priscu JC, ed. Ecosystem Dynamics in a Polar Desert: The McMurdo Dry Valleys. Antarctic Research Series, Vol. 72. Washington (DC): American Geophysical Union.

Wallin DO, Swanson FJ, Marks B. 1994. Landscape pattern response to changes in pattern generation rules-Land-use legacies in forestry. Ecological Applications 4: 569-580.

Ward BB, Priscu JC. 1997. Detection and characterization of denitrifying bacteria from a permanently ice-covered Antarctic lake. Hydrobiologia 347: 57-68.

Wharton RA Jr, Lyons WB, Des Marais DJ. 1993. Stable isotopic biogeochemistry of carbon and nitrogen in perennially ice-covered Antarctic lake. Chemical Geology (Isotope Geoscience Section) 107: 159-172.

Wharton RA Jr, Meyer MA, McKay CP, Mancinelli RL, Simmons GM Jr. 1994. Sediment oxygen profiles in a super-oxygenated Antarctic lake.

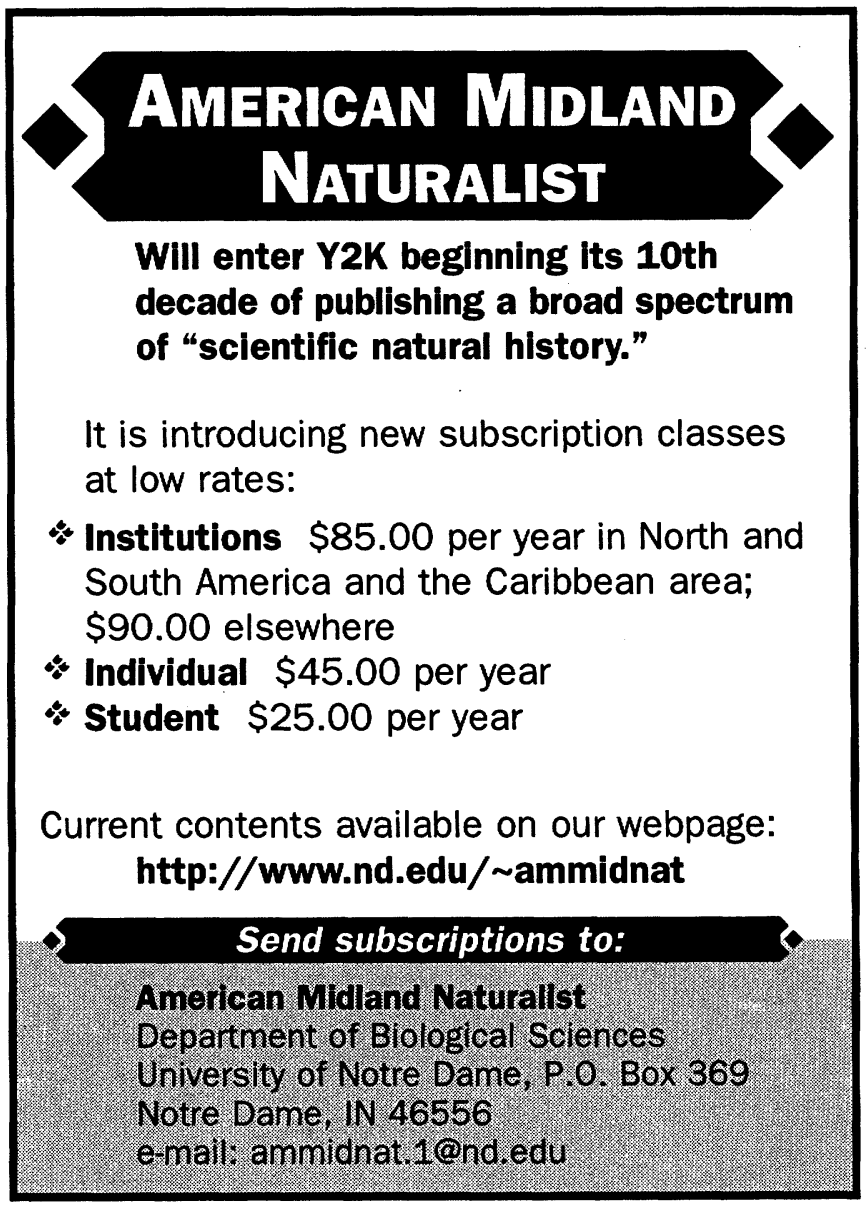

Limnology and Oceanography 39: 839-853.

Wynn-Williams DD, Russell NC, Edwards HGM. 1997. Moisture and habitat structure as regulators for microalgal colonists in diverse Antarctic terrestrial habitats. Pages 77-88 in Lyons WB, Howard-Williams C, Hawes I, eds. Ecosystem Processes in Antarctic Ice-Free Landscapes. Rotterdam (The Netherlands): A. A. Balkema. 